Article

\title{
Sink or Swim? Impacts of Management Strategies on Small Business Survival and Recovery
}

\author{
Maria I. Marshall ${ }^{1, *}$ (D) and Holly L. Schrank ${ }^{2}$ \\ 1 Agricultural Economics, Purdue University, West Lafayette, IN 47907, USA \\ 2 Professor Emeritus of Consumer Sciences and Retailing, Purdue University, West Lafayette, IN 47907, USA; \\ schrankh@purdue.edu \\ * Correspondence: mimarsha@purdue.edu
}

Received: 3 July 2020; Accepted: 27 July 2020; Published: 3 August 2020

\begin{abstract}
The rate of small business demise is exacerbated by exogenous events such as natural disasters that threaten even the healthiest business. This study focused on the effects of management strategies used by small business owners affected by a natural disaster and the resulting recovery status eight years after Hurricane Katrina. The results indicate that location, human resource, and financial management decisions affect operating status and recovery. Both pre-and post-disaster strategies and across system exchanges were utilized and predicted survival and recovery, e.g., financial managerial strategies utilized post disaster predicted whether a business would fully recover, but effective overall management strategies differed over time and operating category.
\end{abstract}

Keywords: small business; disaster; demise; recovery; survival; management strategies; resource exchanges

\section{Introduction}

Small businesses in the United States are often described as having a large collective impact on the nation's economy and on new job creation, yet they are vulnerable to many threats. Business dynamic statistics from the United States Census Bureau indicate that, after five years, businesses in the retail, finance, and construction industries have survival rates below $40 \%$, while those businesses in other industrial sectors average slightly above $50 \%$ [1]. These statistics make clear that significant attrition is normal. However, because of their impact on the U.S. economy, the welfare and survival of small businesses after threats such as extended exogenous shock is important to understand because it likely differs from normal in many respects. Statistics framing demise after natural disasters have been provided by small business administration officials, senators, business organizations, and researchers. These statistics vary widely and the data from which they are derived are rarely mentioned. Furthermore, demise after exogenous shock is not separated from normal attrition in these data. A study of small business demise and recovery following Hurricane Katrina estimated demise using a random sample of small businesses. Results of that study demonstrated that the proportion of small businesses no longer operating after Katrina was 18.9\% for all causes, excluding owner death [2] Some of these businesses never reopened while others reopened and closed at a later date [3]. As time passes, the non-surviving cohort included in the study (all of which were operating at the time of Katrina) is likely to increase in number. These research-based results suggest that demise is a process. The point in time when demise is assessed after an adverse event is important because it influences understanding of the true rate of demise.

The welfare and survival of small businesses is important to understand, not only for the good of an individual business, but also for the community as a whole. Storr et al. [4] noted that entrepreneurs play an important role in helping a community rebound after a natural disaster by providing necessary 
goods and services, restoring and replacing disrupted social networks, and signaling that community recovery is in progress. Because of the belief that entrepreneurial leadership plays an important role in bringing about community recovery, it is logical to consider the extent to which owners themselves are able to rebound and what factors may facilitate recovery or act as deterrents. A first step is to understand how the business is impacted by the disaster shock and the strategies the business uses to contend with the initial exogenous shock as well as potential subsequent shocks which may occur.

Shocks to a small business are typically categorized as exogenous and endogenous. While research has been undertaken to determine endogenous reasons for attrition, the exogenous reasons for demise that can deal a blow to even well run and successful businesses have not been studied as extensively. The impact of successive exogenous and endogenous shocks has not been studied. Further, few researchers have addressed management strategies, particularly in the context of the crisis event such as a hurricane. Brown et al. [5] reported that customer issues were the most disruptive impact for organizations after the Canterbury earthquakes. However, Haynes et al. [6] demonstrated that, across all types of disasters, management strategies were more likely than customer strategies to predict business survival. The present study expands on this scarce literature by analyzing the effect of selected business management strategies on the recovery status of small businesses that experienced the same exogenous natural event with an emphasis on the resource exchanges and interpersonal transactions utilized to work toward recovery.

This paper focuses on small businesses that experienced the exogenous shock of Hurricane Katrina. The purpose of this paper is to examine whether management decisions and strategies influenced the ability of small businesses to recover from Hurricane Katrina. The central focus of this paper is to identify whether significant differences in operating status emerge, and if they do, to offer explanatory evidence and insight about owner management decisions and strategies that may have resulted in different post-disaster outcomes for these businesses. The results of this study would be useful to small business owners as well as to business consultants who advise small businesses on preparation for long-term viability in the face of natural hazards.

\section{Review of Literature}

The following review of literature addresses several topics of relevance to this paper: (1) theoretical overview of sustainability of small businesses; (2) the nature of disruption and shock; (3) small business continuance; and (4) business characteristics that affect recovery, particularly the exchange of resources between the household and the business.

\subsection{Theoretical Overview}

Watson et al. [7] advocated "a holistic understanding of the linkages, dependencies and relationships within a community" (i.e., interacting systems), arguing that households are more than a source of business demand, but are components of the function and production of the business itself with each contributing to the other's welfare economically, psychologically, and through ties and attachments to the community. Households and businesses are part of an interconnected network. A holistic approach is effectively addressed with systems theory.

Systems theory offers principles common to complex entities such as objects, organizations, human beings, and families, positing that change in one entity of the system affects the parts as well as the whole, and that predictable patterns of behavior are demonstrated by each system and sub-system as they interact. Systems theory argues that, during times of disruption and change, interpersonal and resource transactions between systems serve as processes that help to restore stability and support sustainability. The Sustainable Family Business Model (SFBM) was developed as a model to study family business sustainability from a systems perspective. Stafford et al. [8] and Danes et al. [9] applied systems theory to business sustainability and argued that the family, business, and community engage in an exchange of resources and interpersonal transactions. These transactions contribute to the integrity, growth, financial soundness, and structural integrity of the family, business, 
and community sub-systems in the short term as well as to long term business sustainability. While the present study focused on small businesses, the theory provides a useful framework for assessing changes and exchanges among the business, the owner's household, and the community in a post-disaster environment. Figure 1 illustrates this interaction in times of change and in times of stability. The exchange of resources and interpersonal transactions, according to systems theory, occurs in order to return the systems to equilibrium during times of change. It is assumed to be mutually supportive, symbiotic, or complementary, but not necessarily reciprocal.

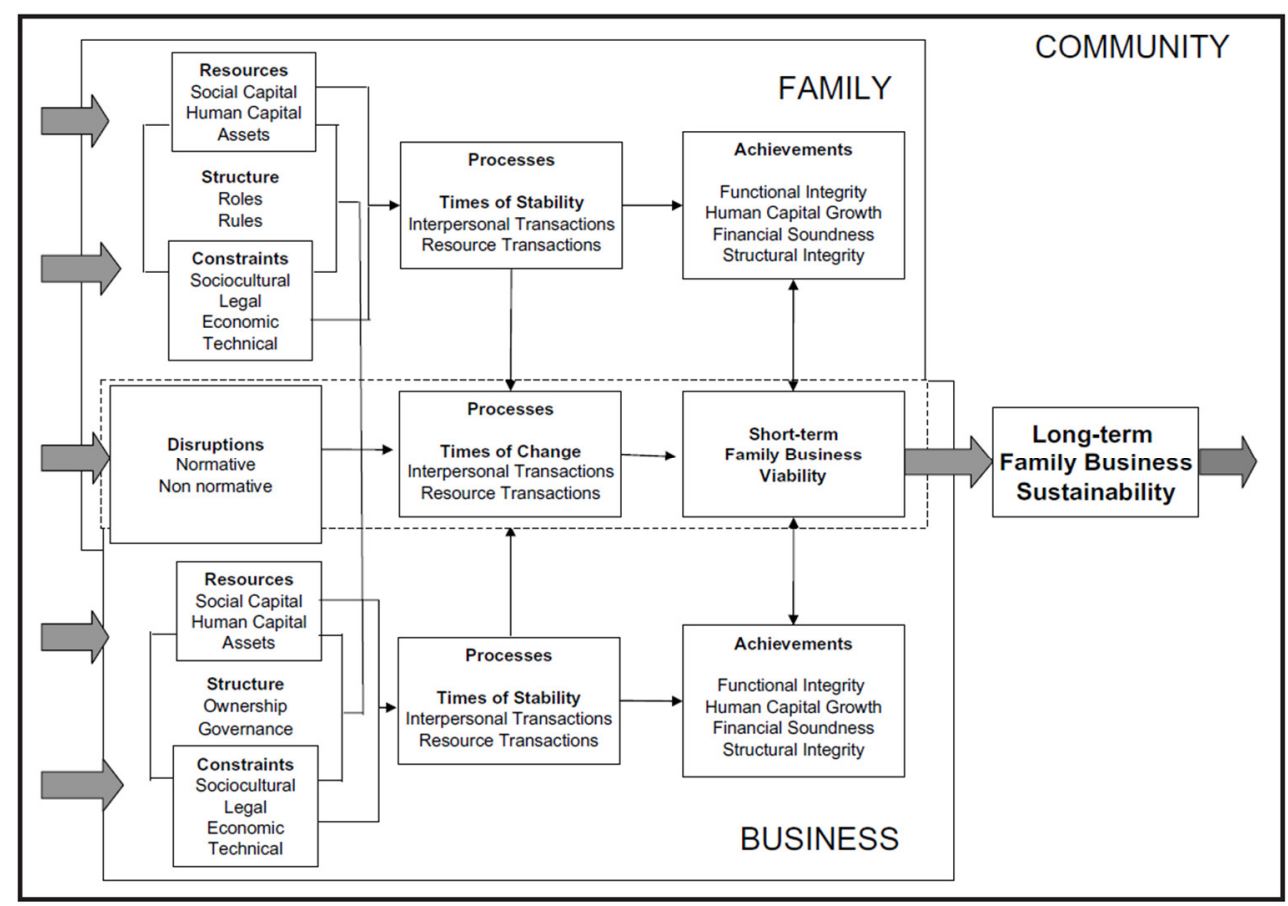

Figure 1. The Sustainable Family Business Model (Danes et al. 2008).

Research has demonstrated that systems theory is a useful basis for understanding small businesses in the context of changing times. Several studies that have utilized the SFBM demonstrate that the model provides a suitable framework for study of the resource exchanges and interpersonal transactions between business, owner's household, and community and demonstrates that these interactions exist and have impacts [10-13]. This line of research confirms the importance of considering household variables as important tools for the understanding of business sustainability, and also confirms that resource and interpersonal transactions between business and household have a business impact. Normative interpersonal and resource transactions do occur between firm and household, they vary across firms, impacts can be documented, and these transactions serve to reestablish an equilibrium between and within systems when disruption occurs. The SFBM model does not address the characteristics of exogenous shock, an important element of understanding business continuance and sustainability. The following literature addresses small business continuance after exogenous shocks such as natural disasters.

\subsection{Nature of Disruptions and Shocks}

Nakagawa [14] classified failure of units or systems in two ways: (1) catastrophic failure because of some sudden shock; and (2) degradation failure that causes units to fail over time as "damage" reaches a critical level. In the context of disaster, businesses may cease to operate for either reason. In some cases, damage to assets and/or primary markets may be insurmountable and the business may never reopen or may close soon after reopening. However, after a natural disaster or exogenous shock, small businesses that reopen may experience multifaceted accumulating factors contributing to 
degradation failure. Such factors are likely to include not only physical damage to business assets but also economic damage. This economic damage may result from loss of utilities, damage to infrastructure such as transportation systems, and loss of customers. In addition, endogenous reasons such as undercapitalization and other factors typical of businesses failing for management reasons remain in play. Sydnor et al. [15] documented that both catastrophic and degradation business failure occurred after Hurricane Katrina. Sydnor and colleagues compared businesses that never reopened to those that were still operating eight years later in 2013. Businesses that reopened after Katrina but ceased to operate by 2013 were also compared to those that were operating in 2013. The two groups of closed businesses exhibited some key differences that indicated those businesses that never reopened had experienced catastrophic failure while the businesses that reopened but ceased operating at a later date were likely victims of degradation failure. This finding adds to the evidence that numerous factors contribute to business discontinuance and/or stability and these factors are both endogenous and exogenous to the organization.

\subsection{Small Business Continuance}

The discussion of business discontinuance and sustainability is complicated by the introduction of an exogenous shock such as a natural disaster or other crisis that is beyond the control of the business owner, especially when it is widely experienced and impacts other systems with which the firm might normally interact. The impact of such exogenous shocks varies considerably depending on characteristics of the owner; of the business (such as its industry, size, financial position, and leadership), decisions made by the owner, and, in the case of natural disaster, the vulnerability of the location of the business and its interacting systems of family and community relative to the disaster's varying impact $[3,15,16]$. For some firms, the consequences may be minimal, but, for others, the consequences may be catastrophic.

Research from the business and disaster literatures has addressed transactions in non-normative times such as after natural disasters. Reasons typically cited for firm demise include lack of resources such as experience and revenues [17]. Management decisions such as poor market timing, location choice, inventory management, overinvestment in fixed assets, personal use of business funds, unexpected growth, and competition are also mentioned as a reason for demise [18]. Further, demise of a successful business can be family related and triggered by "life events" such as death and divorce [17]. Each of these "events" or "conditions" are primarily endogenous disruptions to the equilibrium of the firm and result in exchanges within and across systems aimed at restoring that equilibrium. In some cases, the transactions and exchanges may not be successful, and the firm may not survive.

In the context of a natural disaster (exogenous) shock, disruption extends far beyond individual firms. Businesses, individuals, and households may suffer displacement, loss of property, loss of household members and loss of income, and they may also experience stress and interpersonal conflict. Research has established that individuals may suffer from post-traumatic stress disorder as a result of a disaster [19,20]. Family distress has been shown to have business impacts [17]. Danes et al. [21] pointed out that how business-owning families manage conflict impacts its severity and their resulting quality of life. Stafford et al. [22] demonstrated that having fewer negative family stressors increased the likelihood that a family business would remain open and increase revenue. Thus, the available evidence suggests that additional shock may result from the initial exogenous shock, and that these may contribute to the degree of recovery of an individual business. The following section summarizes the impacts of natural disasters on small businesses as found in disaster literature. A natural disaster can be a significant shock to a business that may significantly influence its vulnerability to demise in both the near term and over time [2,23]. While exogenous shocks impact multiple small businesses they do not necessarily impact small businesses equally, nor in the same manner [24].

Relatively little is written in the traditional business literature about disaster-related impacts on small business outcomes. Most research on small- and medium-sized businesses and extreme events has focused on organizational resilience [25]. However, several studies in the disaster literature 
have examined what happens to small businesses during and after disasters and what factors predict survival or non-survival. The studies have included single hazard type disasters $[2,3,15,26-32]$ as well as multiple hazard types such as earthquakes and hurricanes [6,33-35]. Tierney [36] provided extensive discussion and analysis of the factors that contribute to small business vulnerability, response, and recovery.

\subsection{Business Characteristics That Affect Recovery}

The majority of small business disaster research to date has studied operating firms and has excluded firms that have ceased operations because of the difficulty of locating them post-disaster [37]. However, a few studies have succeeded in locating non-surviving business owners and interviewing them to determine whether operating firms differ from non-operating firms see $[2,3,15,38]$. On the whole, these studies demonstrate that differences do exist between firms that remain in operation and those that do not. The work of Sydnor et al. [15] also suggests that there are likely differences between businesses that survived but still struggle and those that are fully recovered.

What follows is a review of potential differences in post-disaster outcomes, which was addressed in the present study. The discussed variables include both internal firm and owner characteristics as well as variables that relate to exchange of resources between firm and owner's household. In addition, pre- and post-event management strategies are discussed. These variables have been utilized in past research to better understand small business outcomes such as survival, demise, and success.

Pre-existing owner characteristics. Most studies of survivor businesses report that selected pre-existing owner characteristics such as gender, race, education, industry related work experience, and owner's prior disaster experience can impact the activities and sustainability of the business post-disaster. For example, being a female owner is a characteristic negatively associated with business recovery $[3,39,40]$. Being non-white may also be a factor in small business survival [3]; for example, Lindell et al. [41] reported that non-white owners prepare less for disasters; however, Webb et al. [42] reported no significant differences among survivors. At the six months point, prior disaster experience was reported to have a significant impact on recovery time [43].

Pre-existing firm characteristics. In addition to the economic downturn that typically follows a disaster, the pre-existing characteristics of the business itself, particularly its size and financial status impact its post-disaster outcome. Several studies have reported a positive association between firm size prior to the disaster and ability to continue in operation post-disaster $[3,27,28,44]$. In contrast, Brown et al. [5] reported no association between firm size and their disaster recovery index.

In addition to size, the industry sector of the business has also been reported as a factor in continuance by several researchers [3,38,45-49]. Legal form of ownership is also a characteristic that predicts operating/non-operating groups [3,5]. The size of the business and its legal form are indicators of the human and capital resources the owner has built around the business as well as its ability to adapt to new conditions. In a disaster setting, the characteristics and resources of a business may play an important role in determining survival.

Management strategies of successful and unsuccessful small firms. Two primary causes of small business failure are endogenous in nature: management skills (human capital) and adequate financial capital [50-52]. Lussier [53] examined a variety of endogenous factors and created a model to predict success/failure. Significant differences between successful and failed businesses (based on bankruptcy records) included use of professional advice, education of the owner, recruitment and retention of quality staff, and parents who owned a business. These differences reflect the human capital of the businesses and the ability of owners to either manage well or to find additional human capital resources to help them develop management decisions and skills. A model that included 15 factors was developed and tested and found to be approximately $70 \%$ accurate in predicting successful and failed businesses in the sample.

In a subsequent study, Lussier and Halabi [54] tested the success/failure prediction model in three countries. The Lussier model was tested based on the nominal dependent variable (profitable, 
not profitable), and controls of business size, age, and industry were included. The researchers concluded that successful firms differed from failing firms, but differences varied somewhat by country. The researchers suggested that U.S. businesses focus on planning, adequate capital, good record keeping and financial control, managing capital to ensure sales and cash flow, and using professional advice to improve planning. Overall, the model was better at predicting failure than success of U.S. small businesses [54].

Gaskill, Van Auken, and Manning [55] also developed a model of perceived causes of business failure. Failure was defined as wanting or needing to sell or liquidate to avoid loss, or business is not profitable. They identified four principal factors associated with small business failure among Iowa retail businesses. Factor 1 related to managerial and planning functions such as pricing, planning, advertising and promotion, managerial skills, personnel, and product and merchandise. Factor 2 dealt with vendor relations and record keeping. Factor 3 focused primarily on the competitive environment. The final factor appeared to relate to growth and over-expansion, but the reliability of this factor was relatively low. Several items were eliminated from the study based on low factor loadings. These included several internal financial variables: inadequate sales, high operating expenses, undercapitalization, and poor cash flow management. The authors suggested that these factors may be less important depending on the period of time when the firms in their study would have failed (which was an expansionary period) and more important in times of economic distress. One could also speculate that the significance of these factors may vary for other industry sectors and/or according to where the firm may be with respect to its individual growth/decline trajectory. Perhaps implementation of these financial variables for firms still reasonably healthy would be more significant than those that were closer to failing.

These models have not been tested in the context of exogenous shocks such as natural disasters. While natural disasters pose the usual risks of small business attrition, they also add an additional risk of exogenous shock to the business. This additional risk takes the form of physical damage such as potential loss or damage to operating facilities, equipment and inventories; potential loss of customers and suppliers because of damage to the facilities and residences of others; and infrastructure damage to roads and utilities that can lead to significant reduction in ability to conduct business at all. Furthermore, natural disasters pose the risk of loss of income when businesses must remain closed due to loss of public utilities or other disaster conditions.

Based on what is known about business demise and recovery, small businesses that met demise immediately after the original exogenous event had likely suffered greater impacts. For example, Hurricane Katrina inflicted catastrophic damage to buildings, utilities, and roads making certain areas inaccessible for days and months. This leads to the following hypotheses related to disaster impacts and business demise.

Hypothesis 1 (H1). Businesses that suffered more storm damage were less likely to be open in 2013 than businesses with less damage.

Hypothesis 2 (H2). Businesses that experienced greater delays in reopening after Hurricane Katrina were less likely to be open in 2013 than businesses that experienced no delays in reopening after Hurricane Katrina.

Sydnor et al. [15] reported that businesses that did not reopen after Hurricane Katrina were significantly more likely to have suffered physical damage to the business, but this effect was a short-term one and had much less effect on long-term recovery. Thus, these questions must be raised: What factors impact the longer-term recovery of small businesses? Does recovery depend on size and age of the business? How is recovery influenced by management strategies implemented both before and after an exogenous shock?

Management strategies. While there is literature that addresses the pre-disaster preparation of small businesses, there is relatively little research that addresses post-disaster strategy of small businesses. It is important to understand what business owners do because a natural disaster presents a new 
situation and may require different responses (information, strategies, and decisions about business operations) under conditions that vary from "normal". These strategies may involve change from pre-existing owner or business characteristics, or they may represent exchanges of resources between the firm and owning family or firm and community.

One important management strategy is that of choosing an operating location, and there is little evidence to suggest that business owners consider potential disaster impacts when they make the initial location decision. However, choosing an operating location that is less vulnerable to disaster damage can be an important pre-disaster management strategy (for example, away from flood zones and low-lying areas and away from known earthquake fault lines). Businesses that did not survive an earthquake were located in geographic areas with higher levels of shaking intensity [35,42]. Businesses in coastal Mississippi counties were more likely to have met demise than were those operating in non-coastal locations [3]. Choice of location for the business can have a significant impact on the post-disaster outcome of the business.

One post-disaster management decision may be selection of a different operating location that is less vulnerable. Relocating may be a management decision necessitated by business losses, or it can be a powerful means of reducing risk and may be key to business survival. Once a disaster occurs, business operations can potentially be moved to other locations, yet evidence suggests this is not an easy strategy to implement. Tenant business owners often waited for facility repairs and conditions to change, believing they were bound to their location by their lease agreements [37]. In addition, rents are likely to rise post-disaster and suitable locations may be unaffordable or unavailable. However, businesses that rented their operating location recovered slightly better than those that owned the operating property [5]. While the evidence is somewhat mixed, we propose the following hypothesis:

Hypothesis 3 (H3). Businesses that relocated after Hurricane Katrina were more likely to be operating in 2013 than businesses that did not relocate.

Hypothesis 4 (H4). Businesses that relocated after Hurricane Katrina were more likely to be recovered than businesses that did not relocate.

Reaching out to those who can assist the business owner with reopening and recovery is an external business strategy that may be useful post-disaster, i.e. an interpersonal transaction. Watson et al. [7] identified two specific dimensions of households that affected business recovery in Lumberton NC after Hurricane Matthew in 2016. These were whether loss of customers or labor impacted business recovery 15 months post-disaster. Customer loss significantly decreased the likelihood of full business recovery. While employee labor issues stemming from the household had an effect on business recovery, its impact was marginal. Asgary et al. [43] reported that personal savings and support of friends and family had significant impacts on recovery time six months after flood damage but were not major factors in whether or not the businesses were operating at the same level or better off than before the flood disaster. The present study focused on the owner's household and addressed non-routine resource and interpersonal exchanges between business and household such as labor, time (household adjustments), and financial resources (comingling). The present study also addressed household disruptions in terms of residential damage and disruptive life events that may have occurred in the owner's household post-event.

After a disaster, the firm may suffer damage and loss of income, while the household may face its own "life events" such as injury, death, divorce, or loss of job. Both stresses on the firm post-disaster and household life events necessitate management flexibility in the family and business and at their interface [22]. "Family adjustment strategies" represent reallocation of resources such as time and labor during hectic times or, in other words, an exchange of resources and interpersonal transactions between the household and the firm [56]. There were significant differences between surviving and non-surviving business managers in the use of management of time, family labor, and financial resources [16]. Thus, we propose the following hypothesis: 
Hypothesis 5 (H5). Businesses that whose owners implemented household to firm resource allocations were more likely to have recovered from Hurricane Katrina than businesses that did not use these strategies.

Financial management strategies employed by owners after a disaster such as Hurricane Katrina potentially impact recovery. Business-owning families often report that they comingle their household and business financial resources [57]. Haynes et al. reported that this management practice significantly affected the likelihood of firm survival [6]. Using business assets to secure household loans or making business loans to the household was associated with a higher likelihood of survival. The more money the owner took out of the business for the household's use, the more likely the business was to survive. While these variables could be viewed as financial management strategies, they were strong indicators of the financial strength of the owner's household and business [6]. In either case, they are also indicators of the financial thinking and management strategies that firm owners may employ during normative times and in post-disaster periods. This leads to the following hypothesis:

Hypothesis 6 (H6). Business with owners that comingled their business and household finances were more likely to be operating in 2013 and more likely to have recovered from Hurricane Katrina than businesses that did not comingle their finances.

Under-capitalization is commonly viewed as a predictor of small business attrition; therefore, it is logical to assume that level of capitalization and financial strategies are likely to be important pre-existing components of business survival after a crisis. Common financial strategies owners employ post-disaster may include obtaining other financing to bridge the loss of income. In the United States, business owners may work with their banks to postpone loan payments during the time their businesses are unable to operate. Owners may also apply for SBA guaranteed low interest loans [32], a resource transaction between the firm and the community. The literature to date provides mixed evidence on the effects of SBA disaster loans and post-disaster aid on small businesses. Some researchers argued that federal financial assistance in the form of direct loans positively affected small business recovery [58-60]. Businesses in counties receiving more disaster assistance had a higher likelihood of not surviving; however, compared to those located in counties with less disaster assistance, they were more likely to have positive revenue change [6]. In contrast, earlier work found that post-disaster federal loan assistance had a negative effect on business recovery, suggesting that the additional debt load may have hurt recovery $[28,37]$. In general, it appears that both direct and indirect disaster funding can positively impact initial business survival, but it is not clear whether these types of funding support long-term recovery. Thus, we propose the following two hypotheses:

Hypothesis 7 (H7). Businesses that received an SBA loan were more likely to have recovered from Hurricane Katrina than businesses that did not receive an SBA loan.

Hypothesis 8 (H8). Businesses that received special consideration on existing loans payments were more likely to have recovered from Hurricane Katrina than businesses that did not receive special consideration.

\section{Conceptual Framework of Demise, Survival and Recovery}

Much of the literature reviewed here addresses demise and survival in a dichotomous manner, however, it is clear that businesses that never reopen differ in key ways from those that reopen but ultimately do not survive. In addition, there is also evidence that those businesses that do resume operations after a natural disaster do not necessarily recover fully [15]. To better address what contributes to business sustainability, a non-dichotomous assessment of "recovery" is needed. Marshall and Schrank proposed a small business disaster recovery (SBDR) framework (Figure 2) that includes four categories of business operating status: demised, survived, recovered, and resilient and these may be assessed over time [61]. These categories offer insights into the recovery period and its 
characteristics that go beyond those of the initial post-disaster assessment. Permanent closure of a previously operating business is defined as "demise", distinguishing it from" non-operating" which may be temporary (such as rebuilding or not operating because lifeline utilities are not restored). In the framework, "survival" refers generally to the status of an operating business (as opposed to demised business), but specifically to those businesses that were operating at a reduced capacity in terms of revenues. The term "recovered" was applied to businesses that were operating with revenues at a similar level to what they generated prior to the natural disaster. "Resilient" businesses were defined as those operating businesses that had exceeded their pre-disaster status and had taken additional steps to reduce their exposure to future events.

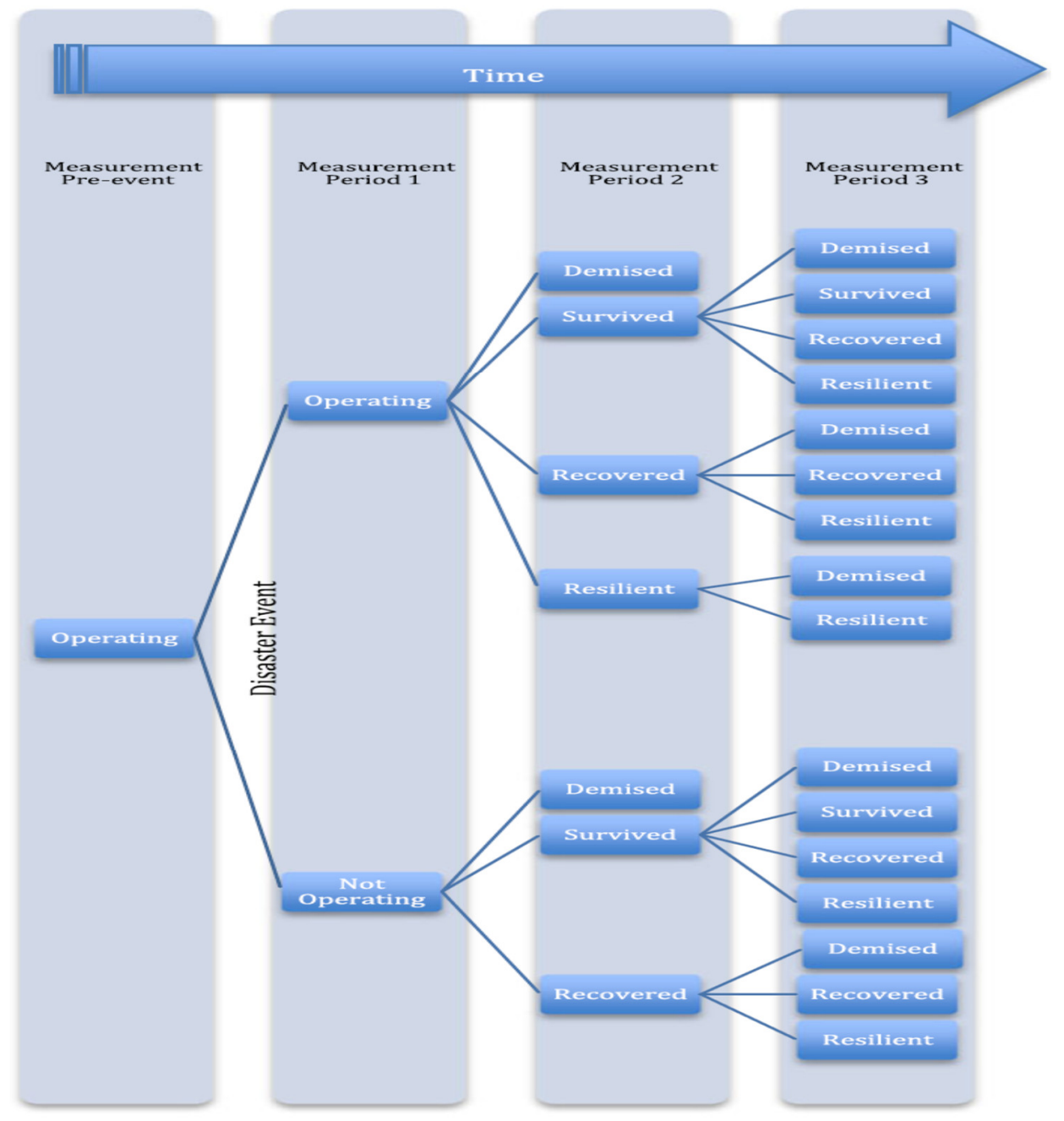

Figure 2. Small Business Disaster Recovery Framework.

The present study focused on the interaction between the small business and the community and household systems with which it interacts, utilizing the SFBM as the underlying theoretical approach and the Marshall and Schrank [61] operating status framework definitions to describe the outcomes. The context of the present study was the disrupting impact of an exogenous natural disaster coupled with the endogenous post-Katrina management decisions of the business owners. These decisions may draw upon resource exchanges between the owner's household and business, as well as whether these transactions are positively associated with the ability of small businesses to fully recover from the shock of a natural disaster. Most prior studies have focused on firm characteristics, demographics, and in-firm strategies. It also seems reasonable to expect that strategy differences in recovery of those businesses still operating will emerge. Those that have successfully recovered are likely to have made 
different decisions and employed more or different strategies than those that are surviving but not recovered. Recovered businesses are also more likely to have been larger, financially stronger, and more successful prior to the disaster than were those businesses just surviving.

\section{Materials and Methods}

At the time it occurred, Hurricane Katrina was the costliest natural disaster in the history of the United States. It was extremely destructive and deadly. It caused severe property damage, particularly along the Mississippi coast. Total property damage was $\$ 108$ billion (2005, USD). Although not the deadliest hurricane in U.S. history, it caused at least 1245 deaths and destroyed or damaged more than 800,000 homes [62]. The total economic impact in Mississippi and Louisiana exceeded $\$ 150$ billion. Over one million people were displaced [63], primarily in Louisiana. While it would have been possible to choose a multi-state sample, we specifically chose Mississippi and not Louisiana (or a combination of the two) as our study area because it reduced the asymmetric impact of decisions made by the governors of the states. In Louisiana, the governor delayed emergency response by the federal authorities and a multitude of other problems arose around decisions of authorities. New Orleans suffered considerable population loss (over 50\%) [63], while the population along the coast of Mississippi largely rebounded but shifted inland [64]. Furthermore, Louisiana experienced the left side of the hurricane, while Mississippi experienced the more impactful right front quadrant. Selecting only one state for data collection minimized those asymmetries.

This study focused on small businesses known to be in operation at the time of Katrina in a ten-county area in southeastern Mississippi. These ten counties were almost entirely in the right front quadrant of Hurricane Katrina. The counties included three coastal counties (Hancock, Harrison, and Jackson) that took the brunt of the storm surge. Two counties (Lamar and Forest) are in the Hattiesburg Metropolitan Statistical Area. Pearl River, Stone, George, Greene, and Perry counties comprise a mix of small town, rural, and national forest areas. These ten counties also represent a wide range of industries ranging from service businesses, retailing, and manufacturing to agriculture and forestry. All ten counties experienced hurricane force winds and flooding.

A sample of 5,500 businesses was randomly selected from the population of 17,060 for-profit small businesses with 200 or fewer employees that were operating in the ten target counties prior to Hurricane Katrina and headquartered in Mississippi. (Specifics of sample selection and vetting can be found in an earlier paper that utilizes the same data [2,3]. Data collected comply with Human Research Program, IRB \#080200646.) The list provider had misclassified a number of the initial 5500 businesses. Businesses classified as operating prior to Katrina when they had ceased operations, as operating within the target region when that was not the case, or as a for-profit business when they were actually non-profits were not eligible for the study. These 623 businesses were screened out, leaving 4877 to be fielded. The University of Wisconsin Survey Research Center conducted 30 min telephone interviews with the subjects in 2013 (Wave 1). The interviewees were given $\$ 2$ in a mailed request for participation and paid an additional $\$ 30$ when the wave one telephone interview was completed. Interview topics included business, owner, and household demographics, hurricane preparations of both business and owner's household, financial information, and post-disaster outcomes (for example, damage, recovery, or demise), owner resilience, and community variables. Of the 4877 cases fielded, 2610 businesses were eligible and had good contact information. Of the 2610 business owners reached, the cooperation rate was $19.12 \%$, providing a sample size of 499 businesses. The 499 businesses were interviewed three times over a period of three years, beginning in 2013, eight years after Hurricane Katrina. Data from Wave 1 were utilized in this study. These data are unique in that they include comprehensive telephone interviews with owners whose businesses met demise as well as owners whose businesses reopened. There are few studies that have incorporated survived, recovered, and demised businesses. This is a rich dataset from which to glean insights on firm sustainability, particularly as disasters (both natural and manmade) continue to occur. 


\subsection{Dependent Variables}

The operating status categories of Marshall and Schrank's framework [61] were modified slightly for the purposes of this study. Business failure was defined in objective operational terms. Businesses that reopened after Katrina but closed by 2013 were defined as demised. Businesses that were still open in 2013 were defined as operating. Of those that were operating as of 2013, businesses with less revenue and decreased perceived success in 2013 than before Katrina were characterized as "survived". Businesses with the same or increased revenue and perceived success than before Katrina were characterized as "recovered". Of the sample of 451 small businesses used in this study, $18 \%$ (81 businesses) reopened but ceased to operate by $2013,46 \%$ (209 businesses) survived Katrina, and 36\% (161 businesses) were classed as recovered. Three demised/operating groups were utilized to characterize the operating status of the businesses included in the study: closed by 2013 (Cby2013), operating/survived (Survived), and operating/recovered (Recovered). Variable definitions are shown in Table 1.

Table 1. Variable Definitions.

\begin{tabular}{|c|c|}
\hline Dependent Variables & Definition \\
\hline Recovered & Gross revenue same or increased and perceived success increased after Katrina \\
\hline Survived & Gross revenue and perceived success decreased after Katrina \\
\hline Cby2013 (Selection Model) & 1 if operating in 2013; 0 if business closed in 2013 \\
\hline Control and Independent Variables & Definition \\
\hline Female Owner & 1 if owner is female; 0 otherwise \\
\hline Services Industry & 1 if business is in service industry; 0 otherwise \\
\hline Business Age & Age of the business as of 2013 \\
\hline Sole Proprietor & 1 if business is sole proprietorship; 0 otherwise \\
\hline Percent $\mathrm{HH}$ Income from Business & Percent of household income that comes from the business \\
\hline Business had Family Employees & 1 if business had family employees; 0 otherwise \\
\hline Delay Due to Damaged Bus Assets & 1 if delay in reopening was due to damage to business assets; 0 otherwise \\
\hline Delay Due to Government & 1 if delay in reopening was due to government restrictions; 0 otherwise \\
\hline Life Events Scale & Scale of life events ranging from 1 (no events) to 6 (many) \\
\hline Exogenous Shock after Katrina & $\begin{array}{c}1 \text { if business was affected by Deepwater Horizon oil spill, flood, or tornado between } \\
\text { Katrina and 2013; } 0 \text { otherwise }\end{array}$ \\
\hline Distance to Storm $(\mathrm{km})$ & Distance to the center of the storm in kilometers \\
\hline Coastal County & 1 if located in coastal county; 0 otherwise \\
\hline Suffered Catastrophic Damage & 1 if damage was catastrophic; 0 otherwise \\
\hline Number of Days Closed & Number of days closed before reopening \\
\hline Relocated & 1 if business relocated after Katrina; 0 otherwise \\
\hline Records Secured Different Location & 1 if records were secured in offsite location; 0 otherwise \\
\hline Family Adjustment Scale & Scale of adjustment strategies ranging from 1(heavy use) to 25 (no use) \\
\hline Comingled Finances Before Katrina & 1 if business comingled business and household finances before Katrina; 0 otherwise \\
\hline Comingled Finances After Katrina & 1 if business comingled business and household finances after Katrina; 0 otherwise \\
\hline Received SBA Loan & 1 if business received SBA loan; 0 otherwise \\
\hline Received Loan Delays from Creditors & 1 if business received loan delays or write downs from creditors; 0 otherwise \\
\hline
\end{tabular}

\subsection{Independent and Control Variables}

Independent variables examined consist of management strategies used by businesses during the recovery process. Post Katrina management strategies include business management strategies such as location, household strategies, and financial strategies. Business management measures such as whether the owner had taken steps to protect business records or relocated the business were also included.

To assess the vulnerability of business operating location, the variables included whether the business operated in a coastal county or not and distance to the eye of the storm. In the case of Hurricane Katrina, large portions of the three coastal counties experienced not only hurricane force winds, but also storm surge. High water mark records as high as $28^{\prime}$ were established as far inland as 6-12 miles and all towns flooded over $90 \%$ in a matter of hours [65]. More than $95 \%$ of the coastal population of Mississippi was impacted by Katrina's surge [66].

Business damage and loss from Katrina was also included and measured in two ways: (1) the number of days closed before reopening; and (2) the extent of damage. The number of days closed after the disaster serves as a proxy measure of income loss since businesses that could not reopen 
were not generating revenue. Reasons for delays in reopening the business (for example, damage to business assets or government restrictions) were included to provide insight about what delayed reopening. The extent of damage was defined as damage to the facility where the business operated (including assets contained in this facility) and was operationalized as whether or not the business owner reported catastrophic damage.

Management strategies also included family adjustment strategies and a set of indicators of the use of time, labor, and place of operations at the interface of the business and household. The strategies include interpersonal and resource transactions between firm and household. The family adjustment strategy measure includes questions such as "When things are hectic at home, how often do family members, other relatives, or friends help in the business without pay so you can spend more time with the family?" and "You put off or skip routine business demands, such as record keeping or file management, to spend more time with the family.", where 0 is never and 4 is always. The family-business adjustment scale is one indicator of the adaptive capacity available to the firm and was captured as a summative scale from seven Likert-type questions with a range of scale scores from 1 to 25 . The scale was adapted from the work of Miller et al. [67]. Family adjustment represents a household resource the firm can draw upon and manage in hectic times.

Financial measures were examined to gain insight into possible business strategies the owner may have employed post-Katrina. Owners indicated whether they had comingled their business and family finances pre and post Katrina. Owners were also asked to report if they had received an SBA disaster loan or had received any loan payment delays from their lenders. These strategies represent resource exchanges between household and firm, and between community and firm, where the resources are external to the firm.

Control variables consist of pre-existing owner and firm characteristics, storm damage and impact, and as well as other shocks experienced by the owner and the business after Hurricane Katrina. Owner and firm characteristics included variables such as gender, age of the business, industry sector, legal form of ownership, and whether the business had family employees.

As a means of understanding the competing challenges small businesses faced after Katrina, a list of significant life changes was incorporated to assess life events occurring post-Katrina. Life events included marriage, separation, death, divorce, detention in jail, being injured, being fired, and retirement stress (adapted from Holmes and Rahe [68]. Such life changes represent situations where the household may need to draw upon firm resources such as owner's time and may offer insight into management decisions to maintain operations or cease operating the businesses. The original scale was intended for use in predicting the onset of illness and the respondent rates each life event as to its required degree of adjustment. The original scale was shortened and modified for the purposes of the present study. The score derived for the present study was simply a summative measure of the total number of eight types of events a household may have experienced during the post-Katrina recovery period and was not weighted for degree of adjustment required. Finally, a measure of additional exogenous shocks experienced by the business such as the Deepwater Horizon oil spill in 2010, floods, or tornados was included in order to explore whether a series of additional shocks contributed to loss of sustainability.

\section{Results}

\subsection{Descriptive Statistics}

The descriptive statistics compare all three operating categories and are shown in Table 2. Recovered businesses (compared to survived and closed businesses) were less likely to have suffered catastrophic damage from Hurricane Katrina and had fewer days closed because of damage. They were also less likely to have suffered delays because of damage to business assets or government restrictions. In addition, they were less likely to have relocated their operations. Recovered businesses compared to survived or closed businesses were less likely to be owned by women, less likely to be sole proprietors, and less likely to be family businesses. 
Table 2. Descriptive statistics comparing closed, survived, and recovered businesses $(N=451)$.

\begin{tabular}{|c|c|c|c|}
\hline & $\begin{array}{c}\text { Closed by } 2013 \\
(\mathrm{~N}=81)\end{array}$ & $\begin{array}{l}\text { Survived } \\
(N=209)\end{array}$ & $\begin{array}{c}\text { Recovered } \\
(\mathrm{N}=161)\end{array}$ \\
\hline & $\begin{array}{l}\text { Percent/Mean } \\
\text { (Std. Dev.) }\end{array}$ & $\begin{array}{l}\text { Percent/Mean } \\
\text { (Std. Dev.) }\end{array}$ & $\begin{array}{l}\text { Percent/Mean } \\
\text { (Std. Dev.) }\end{array}$ \\
\hline Female Owner & 39.51 & 32.06 & $24.84^{b}$ \\
\hline Services Industry & 23.46 & $43.06^{\mathrm{c}}$ & $31.68^{\mathrm{a}}$ \\
\hline Business Age & $23.56(11.70)$ & $29.22(17.95)^{c}$ & $27.67(17.39)^{b}$ \\
\hline Sole Proprietor & 48.10 & 51.46 & $34.16^{\mathrm{ab}}$ \\
\hline Percent HH Income from Business & $56.70(38.94)$ & $69.50(33.08)^{c}$ & $71.73(33.94)^{b}$ \\
\hline Business had Family Employees & 72.84 & 68.42 & $60.87^{b}$ \\
\hline Delay Due to Damaged Bus Assets & 40.00 & 45.41 & $33.96^{\mathrm{a}}$ \\
\hline Delay Due to Government & 32.10 & 39.90 & $18.63^{a b}$ \\
\hline Life Events Scale & $4.34(1.01)$ & $5.03(0.97)^{c}$ & $5.12(0.87)^{b}$ \\
\hline Exogenous Shock after Katrina & 27.16 & $74.64^{c}$ & $52.17^{a b}$ \\
\hline Distance to Storm $(\mathrm{km})$ & $29.12(19.75)$ & $31.12(18.27)$ & $28.05(19.09)$ \\
\hline Coastal County & 65.43 & 72.25 & $57.14^{\mathrm{a}}$ \\
\hline Suffered Catastrophic Damage & 19.75 & 15.46 & $8.75^{\mathrm{ab}}$ \\
\hline Number of Days Closed & $73.31(150.69)$ & $70.32(158.68)^{c}$ & $38.96(130.99)^{a b}$ \\
\hline Relocated & 19.75 & $11.48^{\mathrm{c}}$ & $6.21 \mathrm{ab}$ \\
\hline Records Secured Different Location & 54.32 & 51.67 & 56.52 \\
\hline Family Adjustment Scale & $16.15(5.24)$ & $14.80(4.61)^{\mathrm{c}}$ & $16.46(4.64)^{\mathrm{a}}$ \\
\hline Comingled Finances Before Katrina & 59.26 & 63.16 & $45.91^{\mathrm{ab}}$ \\
\hline Comingled Finances After Katrina & - & 77.51 & $42.50^{\mathrm{a}}$ \\
\hline Received SBA Loan & 4.94 & $17.22^{\mathrm{c}}$ & $14.29^{b}$ \\
\hline Received Loan Delays from Creditors & 11.11 & $22.12^{\mathrm{c}}$ & 18.87 \\
\hline
\end{tabular}

Financially, recovered businesses were less likely to have comingled their finances pre and post Katrina compared to survived and closed businesses, although they were more likely to have a higher percentage of household income coming from the business. Recovered businesses were more likely to have received an SBA loan and special considerations such as loan delays from creditors than closed businesses. Survived businesses were more likely than both recovered and closed businesses to have comingled their finances after Katrina, received an SBA loan, and received loan delays from creditors.

\subsection{Results of Heckman Probit Model}

A Heckman probit selection model was used to examine post Katrina management strategies that may differentiate businesses that were still operating (those that survived versus those that recovered). The Heckman model was used to determine if financial and other management strategies were positively associated with business recovery. After culling for non-responses 312 businesses remained in the sample. The dependent variable for the probit selection equation was 1 if the business was operating as of 2013 and 0 if the business was not operating as of 2013. From the selection equation 261 businesses were selected and 51 were not selected as observations for the recovered versus survived probit model. The dependent variable "recovery status" had two outcomes where 1 was business recovered from Hurricane Katrina and 0 was business survived Hurricane Katrina. The Heckman probit model results are shown in Table 3.

The results indicate that the control variables played an important role in business recovery. Women-owned businesses were less likely to have recovered from Hurricane Katrina. Businesses in the services industry, older businesses, and sole proprietors were also less likely to have recovered. The more household income that came from the business, the more likely the business was to be recovered. Business with family employees were less likely to have recovered from Katrina. 
Table 3. Heckman Probit Model for Recovered after Hurricane Katrina.

\begin{tabular}{|c|c|c|c|}
\hline $\begin{array}{l}\text { Selection Equation for Operating as of } 2013 \\
\text { Reference Category: Demised }\end{array}$ & Coefficient & Robust St. Error & \\
\hline Female Owner & $-0.126^{\tau}$ & 0.068 & \\
\hline Services Industry & $0.410 * * *$ & 0.039 & \\
\hline Sole Proprietor & -0.037 & 0.106 & \\
\hline Business had Family Employees & $-0.331 *$ & 0.144 & \\
\hline Distance to Storm $(\mathrm{km})$ & -0.001 & 0.001 & \\
\hline Coastal County & -0.100 & 0.072 & \\
\hline Suffered Catastrophic Damage & $-0.060 * * *$ & 0.013 & \\
\hline Number of Days Closed & $-0.105 * * *$ & 0.030 & \\
\hline Relocated & $-0.691 * * *$ & 0.169 & \\
\hline Records Secured Different Location & $-0.229^{\tau}$ & 0.133 & \\
\hline Family Adjustment Scale & $-0.013^{* * *}$ & 0.005 & \\
\hline Comingled Finances Before Katrina & $-0.069^{\tau}$ & 0.041 & \\
\hline Received SBA Loan & $0.640^{\tau}$ & 0.377 & \\
\hline Received Loan Delays from Creditors & $0.281^{* * *}$ & 0.086 & \\
\hline Constant & $1.893^{* * *}$ & 0.354 & \\
\hline $\begin{array}{l}\text { Recovered from Hurricane Katrina } \\
\text { Reference Category: Survived }\end{array}$ & Coefficient & Robust St. Error & Marginal Effect \\
\hline Female Owner & $-0.189 * * *$ & 0.044 & $-6.25 \%$ \\
\hline Services Industry & $-0.624 * * *$ & 0.101 & $-20.67 \%$ \\
\hline Business Age & $-0.009^{* * *}$ & 0.001 & $-0.30 \%$ \\
\hline Sole Proprietor & $-0.291 * * *$ & 0.090 & $-9.65 \%$ \\
\hline Percent HH Income from Business & $0.005^{* * *}$ & 0.000 & $0.15 \%$ \\
\hline Business had Family Employees & $-0.081 * *$ & 0.026 & $-2.69 \%$ \\
\hline Distance to Storm $(\mathrm{km})$ & $0.007^{* * *}$ & 0.002 & $0.23 \%$ \\
\hline Coastal County & $-0.340 * * *$ & 0.045 & $-11.26 \%$ \\
\hline Number of Days Closed & $0.040 * * *$ & 0.006 & $1.31 \%$ \\
\hline Delay Due to Damaged Bus Assets & $0.213^{* *}$ & 0.074 & $7.06 \%$ \\
\hline Delay Due to Government & $-0.333^{* *}$ & 0.119 & $-11.03 \%$ \\
\hline Life Events Scale & $-0.114^{* *}$ & 0.040 & $-3.78 \%$ \\
\hline Exogenous Shock after Katrina & $-0.367^{* *}$ & 0.138 & $-12.15 \%$ \\
\hline Family Adjustment Scale & $0.021^{* * *}$ & 0.002 & $0.68 \%$ \\
\hline Records Secured Different Location & 0.170 & 0.174 & $5.64 \%$ \\
\hline Relocated & 0.138 & 0.290 & $4.56 \%$ \\
\hline Comingled Finances After Katrina & $-0.791^{* * *}$ & 0.119 & $-26.20 \%$ \\
\hline Received SBA Loan & 0.029 & 0.023 & $0.95 \%$ \\
\hline Received Loan Delays from Creditors & $0.107^{\tau}$ & 0.061 & $3.55 \%$ \\
\hline Constant & $1.260 * *$ & 0.431 & \\
\hline rho & -1.000 & 0.000 & \\
\hline
\end{tabular}

Significance levels: ${ }^{\tau} p<0.10,{ }^{*} p<0.05,{ }^{* *} p<0.01,{ }^{* * *} p<0.001 ; N=312$ : Selected 261, Non-selected 51 Wald test of indep. eqns. $(\mathrm{rho}=0): \mathrm{chi}^{2}(1)=6799.31$ Prob $>\mathrm{chi}^{2}=0.0000$; Wald $\mathrm{chi}^{2}(2)=1.7 \mathrm{e}+05 \mathrm{prob}>\mathrm{chi}^{2}=0.000$ Note: Base category is survived. Marginal effects at the means and expressed at percentages.

The control variables for other exogenous shocks to the owner and the business after Hurricane Katrina were statistically significant and negative. Owners who experienced more life events such as death of family members or divorce were less likely to have recovered businesses. Additionally, if the business was impacted by any post-Katrina floods, tornados, or the Deepwater Horizon oil spill its was less likely to have recovered.

Table 3 demonstrates that storm damage (H1) and number of days closed $(\mathrm{H} 2)$ in the selection equation-open in 2013 versus closed in 2013-were statistically significant and negative, as hypothesized. Businesses that suffered catastrophic damage were less likely to be open in 2013. Moreover, as the number of days the business remained closed increased, the business was less likely to be open in 2013. Interestingly, if the number of days closed did not lead to business demise, the business was more likely to have recovered from Katrina. If a delay in reopening due to damage to business assets was reported, then the business was more likely to have recovered; however, if a delay due to government restrictions was reported, then the business was less likely to have recovered. 
Businesses that relocated (H3) were less likely to be open in 2013 than businesses that did not relocate. We hypothesized that relocation would be positively associated with recovery; however, business relocation was negatively associated with being open in 2013 (H3) and positive but not statistically significant for being recovered (H4). The location of the business and damage and impact from the hurricane were also statistically significant. The greater was the distance to the center of the storm. the more likely it was that the business recovered. Moreover, if the business was located in a costal county, then it was less likely to recover.

H5 posits that businesses that used family adjustment strategies were more likely to have recovered from Hurricane Katrina. The family adjustment scale was positive and statistically significant, thus H5 was supported by the data. Businesses that used family adjustment strategies were less likely to be operating in 2013, but if operating more likely to be recovered.

H6 posits that owners who comingled their household and business finances were more likely to have recovered from Katrina. However, this variable was negative and statistically significant; thus, $\mathrm{H} 6$ was not supported by the data. Owners who comingled their finances before Katrina were less likely to have operating businesses that those who did not comingle their finances. Moreover, owners who comingled their finances after Katrina were 26\% less likely to have recovered businesses that those that did not comingle their finances.

H7 proposes that businesses that received SBA loans were more likely to recover. SBA loans were positive in both the selection equation and the recovery model, but statistically significant only for being open in 2013. Thus, H7 was partially supported; businesses that received SBA loans were more likely to be open in 2013, but the loan had no statistically significant effect on being recovered. H8 proposes that business that received loan delays were more likely to recover, and this was also supported by the data. Business that received a loan delay were $4 \%$ more likely to have recovered from Hurricane Katrina than those that did not receive a loan delay.

\section{Discussion and Conclusions}

This study assessed the application of systems theory to business practice, as well as role of specific strategic decisions made by small business owners in response to a significant exogenous shock. The results clearly demonstrate the value of using the lens of systems theory to study business response to shock. The results confirm that both personal and resource transactions took place between businesses, families, and the community and that these transactions were related to outcomes. Transactions were in the form of labor (family business and family adjustment), human capital resources (employees or lack of, sole proprietorship; owner gender, and business age), event costs (damage, days closed, and reopening delays), and financial resources (family comingling, loan delay from financial institutions, and SBA loans from government). The resources were pre- and post-disaster, and the transactions were both internal and external management strategies.

Consistent with the framework proposed by Marshall and Schrank [61], the data demonstrate that there was a range of operating outcomes rather than the demised/survived dichotomy typically studied. While some businesses never reopened after Hurricane Katrina, most of them did reopen. For businesses that did reopen, there was evidence that some ultimately failed and others struggled to stay open, while others regained and/or exceeded their pre-Katrina success and revenues.

The results of the study also demonstrate that demise and recovery differ in timing and nature. Owners who opted to reopen their businesses after Katrina not only brought different resources, strengths, and impacts to the disaster event, but they also likely faced different situations and decisions in making their decision to reopen than did owners who did not reopen at all. Businesses that never reopened experienced the rapid onset shock of Hurricane Katrina, perhaps extensive damage, but did not have the characteristics and resources that enabled them to move forward. For those businesses that were able to reopen but eventually closed (Cby2013), the impact of life events intervened and likely impaired the ability of the business to fully recover from Katrina. These findings parallel the differences in catastrophic and degradation failure proposed by Nakagawa and illustrate the notion 
that shock and damage differ in nature, degree, and duration [14]. Businesses that experienced the rapid onset shock but had the ability to reopen were either successful in the long-run or experienced gradual degradation as they adapted to the post-disaster environment. These results underscore the importance of recognizing that businesses recover at different rates and in different ways.

Further, the results of this study indicate that different pre-existing conditions and different post-event management strategies are associated with different outcomes. In addition to the resources of the business and its systemic transactions with other systems, the strategic decisions made in response to an exogenous event play a role in business recovery for those businesses that are able to reopen. The rate of small business demise is significant and exacerbated by events such as natural disasters that affect even the healthiest small business. Strategy employed to meet these challenges has the potential to improve outcomes. For example, the ability to be flexible in terms of location post-disaster is important [37]. One-third of Cby2013 and recovered business owners in this study were tenants, which would have allowed them to relocate their businesses more easily than if they were property owners. However, that decision may prove to be a costly one. Indeed, $20 \%$ of Cby 2013 businesses relocated compared to $12 \%$ of survived and only $8 \%$ of recovered businesses. It is significant to note that Cby2013 businesses had the ability and were more likely to have relocated than survived or recovered businesses, which may have added another financial burden that led to their demise. Thus, the flexibility to relocate in and of itself may not be enough lead to recovery. Nevertheless, location is a valuable asset if it reduces vulnerability to an exogenous event in the first place. Therefore, these results suggest that choice of initial location is a more reliable means to reduce vulnerability to a disaster and aid survival than is relocation after the event.

Physical damage to business assets was not the only factor in survival versus recovery. Post-disaster management strategies also played a key role in recovery. Researchers have indicated that resources exchanged between the householder and the business were key factors in the demise of family businesses $[17,21,22]$. In fact, the results of this study indicate that were these key factors not only in demise but also in recovery. Business owners who comingled their household and business finances were less likely to be recovered. Interestingly, those that used more adjustment strategies at the household/business interface were less likely be open in 2013 but were more likely to be recovered. This household component to recovery may suggest a fundamental weakness in the business and needs further exploration in order to understand its role and the strategies necessary to manage it.

Financial management strategies also played a key role in business recovery. Although there is no clear consensus in the literature regarding the effect of post-disaster financial aid on small business recovery, the results of this study concur with more recent disaster studies [58-60]. Businesses that received an SBA loan were more likely to be operating in 2013, but the loan was not statistically significant to complete recovery compared to those that did not receive the loan. Interestingly, owners who sought out delays to their existing loans were more likely to be operating in 2013 and more likely to have recovered businesses in the long run. Thus, obtaining financing not only to repair and rebuild but also to bridge the loss of income is important; however, not all forms of financing may be beneficial in the long run.

\subsection{Recommendations for Small Business Owners and Advisors}

Small business owners may not be sufficiently considering the vulnerability of a location in the initial decisions about where to locate their businesses. In disaster prone areas, owners would do well to at least consider business locations away from hazards such as flood plains, surge prone areas, and earthquake fault lines. In addition, the decisions to own versus rent the property where the business operates have an impact on disaster outcomes for those businesses able to reopen. Vulnerability can be reduced by leasing the business operating location since the property owner must bear the cost of repairs rather than the business owner. One downside of owning property is that property owners may be constrained financially during the wait for insurance claim settlements. In addition, after Hurricane Katrina many insurers refused to reinsure properties in some areas 
rendering these properties unbuildable and unsellable. While flexibility is important to survival, relocating the business does not guarantee full recovery and may increase costs, thus the initial pre-disaster location decision is of primary importance.

If the business does not suffer catastrophic damage, the management skills employed by the owner become important to lead the business through the disaster recovery process to full recovery. Small businesses are likely to experience income reduction after a disaster, which makes how they handle the need to bridge that income gap important. Not all post-disaster financing opportunities may be favorable in the long run. Keeping financial records in a secure location away from hazards is of key importance since these records will be needed to apply for financial assistance such as an SBA loan. Risk transfer strategies such as flood insurance and business interruption insurance are available to business owners to provide financial compensation for loss of property and income loss due to business disruptions, yet few take advantage of these resources.

Finally, there is a need for owners and business managers themselves to more fully understand their risks and how their own management choices may reduce or increase those risks. Local chambers and county extension offices could partner to create workshops for small business owners and managers to assist them in evaluating business locations for vulnerabilities (as well as the usual factors such as costs and proximity to customers), to negotiate tenant leases to include a disaster related cancellation clause for their protection, to identify their business assets and plan ways to protect those assets in the event of a disaster, and then to implement those plans. Since management decisions and strategies are a significant influence on business recovery, management knowledge becomes a tool against a future crisis or even from the change inherent in the future itself. Owners would benefit from thinking through scenarios and options in advance of a crisis in order to find ways to integrate disaster preparation strategies into their business routines. To this end, perhaps local workshops and mentorship programs tailored to small business owners in vulnerable areas could be developed and a "storm ready" or "earthquake ready" certificate awarded to owners who learn and implement appropriate crisis planning for their businesses.

\subsection{Limitations and Future Research}

Based on the differing nature of recovery illustrated by this study, it is clear that additional study of the timing, nature, and context of recovery would be valuable to understanding the process of recovery of a small business from a natural disaster. The management strategies explored in this study were limited in scope. An in-depth analysis of how small business owners manage their organizations before and after a crisis is recommended including additional household and community resources it was able to employ during recovery. It would also be useful to examine the impact of life events on degradation demise of small businesses that initially survive a natural disaster to determine if the impact is limited to a "distraction" or is interlaced fundamentally with business decisions and operations as Winter et al. indicated [17]. Recent studies have focused on the role of entrepreneurial marketing strategies in business recovery [69,70]. Haeffele et al. [71] suggested that the pandemic of 2020 has shown that entrepreneurial efforts such as marketing strategy can be valuable tools that should not be stifled by policy. Future researchers might focus on entrepreneurial strategies that owners employ in the effort to help their firms recover. The topic was beyond the scope of the present study.

The findings of this study suggest that whether or not a business is vulnerable to a natural disaster is something that can be affected by its size, management structure and strategy, vulnerability of the operating location to hazards, and post-disaster life events that may impact the owner's family. Based the model presented above, the survival and recovery of a small business after a natural disaster is dependent on management decisions made before, during, and after the disaster, and these decisions differ over time and the specific circumstances of the business and family. Whether a business ultimately recovers is also based on application of management adjustment strategies by the owner and other managers of the business, particularly financial strategies. Owners of small firms need to reach not just within the firm, but also outward to family and community resources when they are working for the 
survival of their businesses. Sustainability is enhanced by exercising management strategies that use both internal and external resources as the SFBM indicates.

Finally, we believe it is important to gather data about the experience of owners of businesses that met demise. Their experience is different and valuable to understand. In addition, it is important to recognize that small businesses are not islands floating in a sea of commerce, but systems that interact with other systems such as households of owners and employees, customers, community agencies, financial institutions, government institutions, the environment, and other businesses. In times of crisis, the "bridges and boundaries" between these systems are important lifelines that should not be overlooked by researchers attempting to understand small business recovery.

Author Contributions: Conceptualization, H.L.S. and M.I.M.; methodology, M.I.M. and H.L.S.; formal analysis, M.I.M.; data curation, H.L.S. and M.I.M.; writing—original draft preparation, H.L.S. and M.I.M.; writing—review and editing, H.L.S. and M.I.M.; and funding acquisition, M.I.M. and H.L.S. All authors have read and agreed to the published version of the manuscript.

Funding: This article reports results from Purdue University Project "Small Business Survival and Demise after a Natural Disaster". Funding for this project was received from National Science Foundation grant \#0856221, Civil, Mechanical and Manufacturing Innovation Division.

Acknowledgments: The authors thank the Mississippi small business owners who participated in the study.

Conflicts of Interest: The authors declare no conflict of interest. The funders had no role in the design of the study; in the collection, analyses, or interpretation of data; in the writing of the manuscript, or in the decision to publish the results.

\section{References}

1. Jorden, R. What Are the Real Small Business Survival Rates? Available online: https://www.linkedin.com/pulse/ 20140915223641-170128193-what-are-the-real-small-business-survival-rates (accessed on 18 January 2019).

2. Schrank, H.L.; Marshall, M.I.; Hall-Phillips, A.; Wiatt, R.F.; Jones, N.E. Small-business demise and recovery after Katrina: Rate of survival and demise. Nat. Hazards 2013, 65, 2353-2374. [CrossRef]

3. Marshall, M.I.; Niehm, L.S.; Sydnor, S.B.; Schrank, H.L. Predicting small business demise after a natural disaster: An analysis of pre-existing conditions. Nat. Hazards 2015, 79, 331-354. [CrossRef]

4. Storr, V.H.; Haeffele-Balch, S.; Grube, L.E. Community Revival in the Wake of Disaster: Lessons in Local Entrepreneurship; Perspectives from Social Economics; Palgrave Macmillan US: New York, NY, USA, 2015; ISBN 978-1-137-28608-6.

5. Brown, C.; Stevenson, J.; Giovinazzi, S.; Seville, E.; Vargo, J. Factors influencing impacts on and recovery trends of organisations: Evidence from the 2010/2011 Canterbury earthquakes. Int. J. Disaster Risk Reduct. 2015, 14, 56-72. [CrossRef]

6. Haynes, G.W.; Danes, S.M.; Stafford, K. Influence of Federal Disaster Assistance on Family Business Survival and Success: Family Business Survival and Success. J. Conting. Crisis Manag. 2011, 19, 86-98. [CrossRef]

7. Watson, M.; Xiao, Y.; Helgeson, J.; Dillard, M. Importance of Households in Business Disaster Recovery. Nat. Hazards Rev. 2020, 21, 05020008. [CrossRef]

8. Stafford, K.; Duncan, K.A.; Dane, S.; Winter, M. A Research Model of Sustainable Family Businesses. Fam. Bus. Rev. 1999, 12, 197-208. [CrossRef]

9. Danes, S.M.; Lee, J.; Stafford, K.; Heck, R.K.Z. The effects of ethnicity, families and culture on entrepreneurial experience: An extension of sustainable family business theory. J. Dev. Entrep. 2008, 13, 229-268. [CrossRef]

10. Haynes, G.W.; Walker, R.; Rowe, B.R.; Hong, G.-S. The Intermingling of Business and Family Finances in Family-Owned Businesses. Fam. Bus. Rev. 1999, 12, 225-239. [CrossRef]

11. Olson, P.D.; Zuiker, V.S.; Danes, S.M.; Stafford, K.; Heck, R.K.Z.; Duncan, K.A. The impact of the family and the business on family business sustainability. J. Bus. Ventur. 2003, 18, 639-666. [CrossRef]

12. Danes, S.M.; Stafford, K.; Haynes, G.; Amarapurkar, S.S. Family Capital of Family Firms: Bridging Human, Social, and Financial Capital. Fam. Bus. Rev. 2009, 22, 199-215. [CrossRef]

13. Danes, S.M.; Lee, J.; Amarapurkar, S.; Stafford, K.; Haynes, G.; Brewton, K.E. Determinants of family business resilience after a natural disaster by gender of business owner. J. Dev. Entrep. 2009, 14, 333-354. [CrossRef]

14. Nakagawa, T. Shock and Damage Models in Reliability Theory; Springer Science \& Business Media: Berlin, Germany, 2007; ISBN 978-1-84628-442-7. 
15. Sydnor, S.; Niehm, L.; Lee, Y.; Marshall, M.; Schrank, H. Analysis of post-disaster damage and disruptive impacts on the operating status of small businesses after Hurricane Katrina. Nat. Hazards 2017, 85, 1637-1663. [CrossRef]

16. Niehm, L.S.; Miller, N.J.; Shelley, M.C.; Fitzgerald, M.A. Small family business survival: Strategies for coping with overlapping family and business demands. J. Dev. Entrep. 2009, 14, 209-232. [CrossRef]

17. Winter, M.; Danes, S.M.; Koh, S.-K.; Fredericks, K.; Paul, J.J. Tracking family businesses and their owners over time: Panel attrition, manager departure and business demise. J. Bus. Ventur. 2004, 19, 535-559. [CrossRef]

18. Mason, M.K. What Causes Small Businesses to Fail?-SBA, Management Skills, Bankruptcy, Capital, Competition, Start-Ups, Financing. Available online: http://www.moyak.com/papers/small-business-failure. html (accessed on 1 July 2020).

19. Perilla, J.L.; Norris, F.H.; Lavizzo, E.A. Ethnicity, Culture, and Disaster Response: Identifying and Explaining Ethnic Differences in PTSD Six Months after Hurricane Andrew. J. Soc. Clin. Psychol. 2002, 21, 20-45. [CrossRef]

20. Perrin, M.A.; DiGrande, L.; Wheeler, K.; Thorpe, L.; Farfel, M.; Brackbill, R. Differences in PTSD Prevalence and Associated Risk Factors Among World Trade Center Disaster Rescue and Recovery Workers. Aust. J. Pharm. 2007, 164, 1385-1394. [CrossRef]

21. Danes, S.M.; Leichtentritt, R.D.; Metz, M.E.; Huddleston-Casas, C. Effects of Conflict Styles and Conflict Severity on Quality of Life of Men and Women in Family Businesses. J. Fam. Econ. Issues 2000, 21, 259-286. [CrossRef]

22. Stafford, K.; Danes, S.M.; Haynes, G.W. Long-term family firm survival and growth considering owning family adaptive capacity and federal disaster assistance receipt. J. Fam. Bus. Strategy 2013, 4, 188-200. [CrossRef]

23. Doern, R. Entrepreneurship and crisis management: The experiences of small businesses during the London 2011 riots. Int. Small Bus. J. 2016, 34, 276-302. [CrossRef]

24. National Research Council; Division on Earth and Life Studies; Commission on Geosciences, Environment and Resources; Committee on Assessing the Costs of Natural Disasters. The Impacts of Natural Disasters: A Framework for Loss Estimation; National Academies Press: Washington, DC, USA, 1999; ISBN 978-0-309-18454-0.

25. Haase, A.; Eberl, P. The Challenges of Routinizing for Building Resilient Startups. J. Small Bus. Manag. 2019, 57, 579-597. [CrossRef]

26. Dahlhamer, J.M.; Reshaur, L. Businesses and the 1994 Northridge Earthquake: An Analysis of Pre-and Post-Disaster Preparedness; Disaster Research Center: Newark, NJ, USA, 1996.

27. Dahlhamer, J.M.; Tierney, K.J. Winners and Losers: Predicting Business Disaster Recovery Outcomes Following the Northridge Earthquake; Disaster Research Center: Newark, NJ, USA, 1996.

28. Dahlhamer, J.M.; Tierney, K.J. Rebounding from disruptive events: Business recovery following the Northridge earthquake. Sociol. Spectr. 1998, 18, 121-141. [CrossRef]

29. Eguchi, R.T.; Goltz, J.D.; Taylor, C.E.; Chang, S.E.; Flores, P.J.; Johnson, L.A.; Seligson, H.A.; Blais, N.C. Direct Economic Losses in the Northridge Earthquake: A Three-Year Post-Event Perspective. Earthq. Spectra 1998, 14, 245-264. [CrossRef]

30. Guion, D.T.; Scammon, D.L.; Borders, A.L. Weathering the Storm: A Social Marketing Perspective on Disaster Preparedness and Response with Lessons from Hurricane Katrina. J. Public Policy Mark. 2007, 26, $20-32$. [CrossRef]

31. Josephson, A.; Schrank, H.; Marshall, M. Assessing preparedness of small businesses for hurricane disasters: Analysis of pre-disaster owner, business and location characteristics. Int. J. Disaster Risk Reduct. 2017, 23, 25-35. [CrossRef]

32. Josephson, A.; Marshall, M.I. The Demand for Post-Katrina Disaster Aid: SBA Disaster Loans and Small Businesses in Mississippi. J. Conting. Crisis Man 2016, 24, 264-274. [CrossRef]

33. Dahlhamer, J.; D'Souza, M.J. Determinants of Business Disaster Preparedness in Two U.S. Metropolitan Areas; Disaster Research Center: Newark, NJ, USA, 1995; Available online: http://udspace.udel.edu/handle/19716/ 632 (accessed on 1 July 2020).

34. Dahlhamer, J.M.; Tierney, K.J.; Webb, G.R. Predicting Business Financial Losses in the 1989 Loma Prieta and 1994 Northridge Earthquakes: Implications for Loss Estimation Research; Disaster Research Center: Newark, NJ, USA, 1999.

35. Webb, G.R.; Tierney, K.J.; Dahlhamer, J.M. Businesses and Disasters: Empirical Patterns and Unanswered Questions. Nat. Hazards Rev. 2000, 1, 83-90. [CrossRef]

36. Tierney, K. Disasters: A Sociological Approach; Wiley: Hoboken, NJ, USA, 2019; ISBN 978-0-7456-7101-7.

37. Alesch, D.J.; Holly, J.N.; Mittler, E.; Nagy, R. Organizations at Risk: What Happens When Small Businesses and Not-For-Profits Encounter Natural Disasters; Public Entity Risk Institute PERI: Fairfax, VA, USA, 2001. 
38. Lam, N.S.N.; Arenas, H.; Pace, K.; LeSage, J.; Campanella, R. Predictors of Business Return in New Orleans after Hurricane Katrina. PLoS ONE 2012, 7, e47935. [CrossRef]

39. Fothergill, A. Gender, Risk, and Disaster. Int. J. Mass Emerg. Disasters 1996, 14, 33-56.

40. Dooley, D.; Catalano, R.; Mishra, S.; Serxner, S. Earthquake Preparedness: Predictors in a Community Survey1. J. Appl. Soc. Psychol. 1992, 22, 451-470. [CrossRef]

41. Lindell, M.K.; Prater, C.S. Household Adoption of Seismic Hazard Adjustments: A Comparison of Residents in Two States. Int. J. Mass Emerg. Disasters 2000, 18, 317-338.

42. Webb, G.R.; Tierney, K.J.; Dahlhamer, J.M. Predicting long-term business recovery from disaster: A comparison of the Loma Prieta earthquake and Hurricane Andrew. Glob. Environ. Chang. Part B Environ. Hazards 2002, 4, 45-58. [CrossRef]

43. Asgary, A.; Anjum, M.I.; Azimi, N. Disaster recovery and business continuity after the 2010 flood in Pakistan: Case of small businesses. Int. J. Disaster Risk Reduct. 2012, 2, 46-56. [CrossRef]

44. Drabek, T.E. Understanding Tourists during Disaster. Aust. J. Emerg. Manag. 1996, 11, 14.

45. Wasileski, G.; Rodríguez, H.; Diaz, W. Business closure and relocation: A comparative analysis of the Loma Prieta earthquake and Hurricane Andrew. Disasters 2011, 35, 102-129. [CrossRef]

46. Tierney, K.J. Social Inequality, Hazards, and Disasters; Political Science: Whitewater, WI, USA, 2006.

47. Chang, S.E.; Falit-Baiamonte, A. Disaster vulnerability of businesses in the 2001 Nisqually earthquake. Glob. Environ. Chang. Part B Environ. Hazards 2002, 4, 59-71. [CrossRef]

48. Han, Z.; Nigg, J. The influences of business and decision makers' characteristics on disaster preparedness-A study on the 1989 Loma Prieta earthquake. Int. J. Disaster Risk Sci. 2011, 2, 22-31. [CrossRef]

49. Lam, N.S.N.; Pace, K.; Campanella, R.; LeSage, J.; Arenas, H. Business Return in New Orleans: Decision Making Amid Post-Katrina Uncertainty. PLoS ONE 2009, 4, e6765. [CrossRef]

50. Peterson, R.A.; Kozmetsky, G.; Ridgway, N.M. Perceived Causes of Small Business Failures: A Research Note. Am. J. Small Bus. 1983, 8, 15-19. [CrossRef]

51. Hall, G.; Young, B. Factors Associated with Insolvency amongst Small Firms. Int. Small Bus. J. 1991. [CrossRef]

52. Scherr, F. Causality, Regression, Discriminant Analysis, and Research on Failure. Akron Bus. Econ. Rev. 1989, 20,8 .

53. Lussier, R.N. A nonfinancial business success versus failure prediction mo. J. Small Bus. Manag. Milwaukee 1995, 33, 8.

54. Lussier, R.N.; Halabi, C.E. A Three-Country Comparison of the Business Success versus Failure Prediction Model. J. Small Bus. Manag. 2010, 48, 360-377. [CrossRef]

55. Gaskill, L.R.; Van Auken, H.E.; Manning, R.A. A Factor Analytic Study of the Perceived Causes of Small Business Failure. J. Small Bus. Manag. 1993, 31, 18.

56. Fitzgerald, M.A.; Winter, M.; Miller, N.J.; Paul, J. Adjustment Strategies in the Family Business: Implications of Gender and Management Role. J. Fam. Econ. Issues 2001, 22, 265-291. [CrossRef]

57. Xiao, J.J.; Alhabeeb, M.J.; Hong, G.-S.; Haynes, G.W. Attitude toward Risk and Risk-Taking Behavior of Business-Owning Families. J. Consum. Aff. 2001, 35, 307-325. [CrossRef]

58. Davlasheridze, M.; Geylani, P.C. Small Business vulnerability to floods and the effects of disaster loans. Small Bus. Econ. 2017, 49, 865-888. [CrossRef]

59. Dietch, E.A.; Corey, C.M. Predicting long-term business recovery four years after Hurricane Katrina. Manag. Res. Rev. 2011, 34, 311-324. [CrossRef]

60. Hiramatsu, T.; Marshall, M. The Long-Term Impact of Disaster Loans: The Case of Small Businesses after Hurricane Katrina. Sustainability 2018, 10, 2364. [CrossRef]

61. Marshall, M.I.; Schrank, H.L. Small business disaster recovery: A research framework. Nat. Hazards 2014, 72, 597-616. [CrossRef]

62. University of Rhode Island Hurricanes: Science and Society: Katrina Impacts. Available online: http: //www.hurricanescience.org/history/studies/katrinacase/impacts/ (accessed on 2 July 2020).

63. Plyer, A. Facts for Features: Katrina Impact. Available online: https://www.datacenterresearch.org/dataresources/katrina/facts-for-impact/ (accessed on 2 July 2020).

64. Robertson, C. Mississippi's Recovery after Katrina Holds Lessons for Policy Makers; The New York Times: New York, NY, USA, 2015.

65. Sun Herald: Katrina Our Tsunami. Available online: http://media.sunherald.com/katrina/ (accessed on 2 July 2020). 
66. Kieper, M. Katrina's Surge, Part 10. Available online: https://www.wunderground.com/hurriane/Katrinas_ surge_part10.asp. (accessed on 4 April 2019).

67. Miller, N.J.; Fitzgerald, M.A.; Winter, M.; Paul, J. Exploring the Overlap of Family and Business Demands: Household and Family Business Managers' Adjustment Strategies. Fam. Bus. Rev. 1999, 12, 253-268. [CrossRef]

68. Holmes, T.H.; Rahe, R.H. The social readjustment rating scale. J. Psychosom. Res. 1967, 11, 213-218. [CrossRef]

69. Morrish, S.C.; Jones, R. Post-disaster business recovery: An entrepreneurial marketing perspective. J. Bus. Res. 2020, 113, 83-92. [CrossRef]

70. Miles, M.P.; Lewis, G.K.; Hall-Phillips, A.; Morrish, S.C.; Gilmore, A.; Kasouf, C.J. The influence of entrepreneurial marketing processes and entrepreneurial self-efficacy on community vulnerability, risk, and resilience. J. Strateg. Mark. 2016, 24, 34-46. [CrossRef]

71. Haeffele, S.; Hobson, A.; Storr, V.H. Coming Back from Covid-19: Lessons in Entrepreneurship from Disaster Recovery Research; Social Science Research Network: Rochester, NY, USA, 2020.

(C) 2020 by the authors. Licensee MDPI, Basel, Switzerland. This article is an open access article distributed under the terms and conditions of the Creative Commons Attribution (CC BY) license (http://creativecommons.org/licenses/by/4.0/). 